Brigham Young University Law School

BYU Law Digital Commons

Faculty Scholarship

$1-1-2007$

Uncivil Religion: Judeo-Christianity and the Ten Commandments

Frederick Mark Gedicks

BYU Law, gedicksf@law.byu.edu

Roger Hendrix

Follow this and additional works at: https://digitalcommons.law.byu.edu/faculty_scholarship

Part of the First Amendment Commons, and the Religion Law Commons

Recommended Citation

Frederick Mark Gedicks \& Roger Hendrix, Uncivil Religion: Judeo-Christianity and the Ten Commandments, 110 W. VA. L. REV. 275 (2007).

This Article is brought to you for free and open access by BYU Law Digital Commons. It has been accepted for inclusion in Faculty Scholarship by an authorized administrator of BYU Law Digital Commons. For more information, please contact hunterlawlibrary@byu.edu. 


\title{
UNCIVIL RELIGION: JUDEO-CHRISTIANITY AND THE TEN COMMANDMENTS*
}

\author{
Frederick Mark Gedicks** \\ Roger Hendrix*"
}

"With respect to public acknowledgment of religious belief, it is entirely clear from our Nation's historical practices that the Establishment Clause permits th[e] disregard of polytheists and believers in unconcerned deities, just as it permits the disregard of devout atheists."

\section{Justice Antonin Scalia ${ }^{\ddagger}$}

I. INTRODUCTION: THE PERMISSIBLE ESTABLISHMENT? .......................276

II. VARIETIES OF AMERICAN CIVIL RELIGION ……..............................279

A. The Established Church ....................................................2279

B. "Nonsectarian" Christianity ...............................................28

C. Judeo-Christianity ............................................................281

III. BEYOND JUDEO-CHRISTIANITY .................................................284

A. Unbelief and Eastern Religion ...........................................284

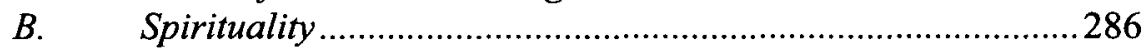

C. Barely Believing ............................................................287

IV. THE "SECTARIANIZATION" OF JUDEO-CHRISTIANITY .........................289

- Copyright $@ 2007$ Frederick Mark Gedicks \& Roger Hendrix. All rights reserved.

We are grateful for the comments and criticisms of Dan Conkle, Ken Karst, Doug Laycock, Lance Long, Michael Perry, Steve Smith, and Mark Tushnet. We also benefited from discussions of earlier versions of this Essay at a workshop at Brigham Young University Law School, at symposia at the University of North Carolina School of Law and Cardozo Law School, at the 2007 Annual Meeting of the Association for the Study of Law, Culture and the Humanities, and, of course, during the Symposium itself at the West Virginia University College of Law. BYU Research Librarian Galen Fletcher provided indispensable assistance in locating sources, and BYU law students Curtis Bentley, Todd Goodsell, and (especially) Nathan Whittaker provided excellent research assistance. All errors that remain are ours.

** Guy Anderson Chair \& Professor of Law, J. Reuben Clark Law School, Brigham Young University, Provo, Utah. B.A., Brigham Young University; J.D., University of Southern California.

*** President, Hendrix Consulting, Salt Lake City, Utah. B.A., California State University at Long Beach; M.A., Brigham Young University; Ed.D., University of Southern California

‡ McCreary County v. ACLU of Ky., 545 U.S. 844, 893 (2005) (Scalia, J., dissenting). 


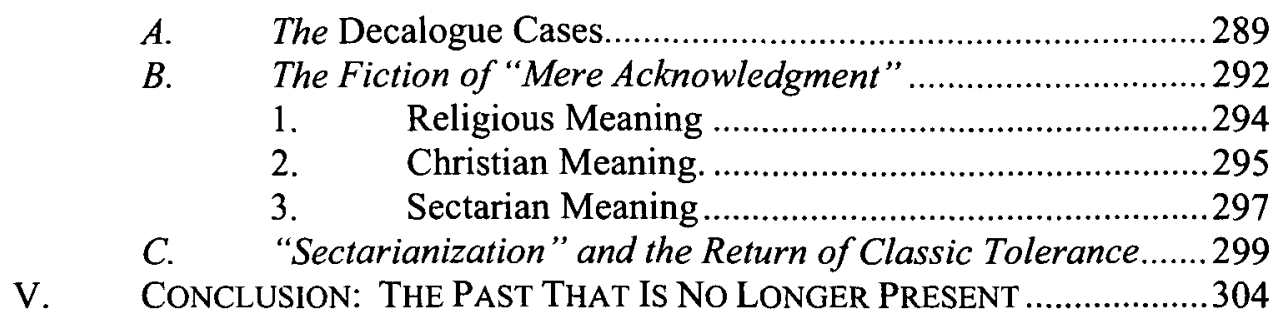

\section{INTRODUCTION: THE PERMISSIBLE ESTABLISHMENT?}

In the recent Decalogue Cases, ${ }^{1}$ Justice Scalia conceded that government cannot invoke the blessings of "God," or even say his name, "without contradicting the beliefs of some people that there are many gods, or that God or the gods pay no attention to human affairs."2 Nevertheless, Justice Scalia declares that this contradiction is of no constitutional moment, because the historical understanding of the Establishment Clause permits government wholly to ignore those who do not subscribe to monotheism. ${ }^{3}$ Noting that more than $97 \%$ of American believers are either Christians, Jews, or Muslims, Justice Scalia concludes that government invocation or endorsement of belief in a monotheistic God does not violate the Establishment Clause. ${ }^{4}$

Justice Scalia's opinion represents the latest effort to insulate American civil religion from Establishment Clause attack. A "civil religion" is a set of nondenominational values, symbols, rituals, and assumptions by means of which a country interprets its secular history. ${ }^{5}$ Civil religion aims to bind citi-

1 McCreary County v. ACLU of Ky., 545 U.S. 844 (2005); Van Orden v. Perry, 545 U.S. 677 (2005). Van Orden and McCreary County were handed down less than two years after the Court denied review in a divisive, high-profile case involving placement of a decalogue monument in the Alabama state courthouse by then-Alabama Chief Justice Roy Moore. See Moore v. Glassroth, 335 F.3d 1282 (11th Cir. 2003), cert. denied, 540 U.S. 1000 (2003); see also Stone v. Graham, 449 U.S. 39 (1980) (invalidating for lack of a secular purpose state-mandated posting of Ten Commandments in public schools with notice advising that Commandments are the foundation of contemporary western and American law).

2 McCreary County, 545 U.S. at 893 (Scalia, J., dissenting).

3 Id. Surely one of the most remarkable judicial declarations in contemporary Establishment Clause jurisprudence, this statement confirms, as Professor Gey has put it, that Justice Scalia is willing to say out loud what most judges dare only to think.

$4 \quad I d$.

5 See Robert Bellah, The Broken Covenant: American Civil Religion in Time of Trial 3 (1975).

The concept of a "civil religion" was first employed by Rousseau, to refer to a set of purportedly universal religious beliefs that government was obligated to encourage to ensure social stability. See Jean JaCQues Rousseau, The Social ConTract bk.4, ch.8, at 130 (Roger D. Masters ed., Judith R. Masters trans., New York, St. Martin's, 1978) (1762) ("There is . . a purely civil profession of faith, the articles of which are for the sovereign to establish, not exactly as religious 
zens to their nation and government with widely shared religious beliefs, thereby supplying a spiritual interpretation of national history that suffuses it with transcendent meaning and purpose. ${ }^{6}$

Since the founding era, successive versions of civil religion have framed loyalty to the United States as a religious commitment as well as a purely civic one. ${ }^{7}$ American civil religion thus filled the role played by the Anglican establishment in England, ascribing theological or spiritual meaning to the events of America's founding and history, and thereby encouraging the social and political cohesion thought necessary for the effective functioning of republican government. $^{8}$

The most recent incarnation of American civil religion is the "JudeoChristian tradition," which emerged in the 1950s as a set of broad, even superficial, "spiritual" values that was thought to be held by virtually all Americans. ${ }^{9}$ Its originally vacuous content was captured by President Eisenhower's famously awkward observation that American government "makes no sense, unless it is founded in a deeply felt religious faith-and I don't care what it is."10 As Will Herberg perceptively observed, Judeo-Christianity was less about the substance of religious belief than about believing in religious belief. ${ }^{11}$

Like President Eisenhower, Justice Scalia seems unaware that even the theologically thin tradition of Judeo-Christianity no longer captures the breadth of religious belief among all or nearly all Americans, if it ever did. ${ }^{12}$ Dramatic

dogmas, but as sentiments of sociability without which it is impossible to be a good citizen or a faithful subject."); see also id. at 127-28.

[The religion of the citizen], inscribed in a single country, gives it its Gods, its own tutelary patrons. Its dogma, rites, and external cult are prescribed by laws. Outside the single nation that observes it, everything is considered infidel, foreign, barbarous; it only extends the duties and rights of man as far as its altars.

Id.

6 Yehudah Mirsky, Note, Civil Religion and the Establishment Clause, 95 YALE L.J. 1237, 1250 (1986); Michael Walzer, Drawing the Line: Religion and Politics, 1999 UTAH L. REV. 619, 621 (1999).

7 See infra Part II.

8 See infra text accompanying notes 17-33.

9 See infra text accompanying notes 34-56.

10 Will Herberg, Protestant-Catholic-Jew 97 (1956) (emphasis omitted) (quoting Gen. Dwight D. Eisenhower, Address at Freedoms Foundation Director's Meeting (Dec. 22, 1952), reported in President-Elect Says Soviet Demoted Zhukov Because of Their Friendship, N.Y. TIMES, Dec. 23, 1952, at 1).

11 Id. at 98 (arguing that American religion is not devoted to "God," but to "religion": "The faith is not in God but in faith; we worship not God but our own worshiping."); see also NoAH FELDMAN, DividED BY GOD 165 (2005) ("Americans of the 1950s developed a public language for speaking about religion in which they emphasized the importance of belonging to a church without specifying the beliefs that membership might entail.").

12 See infra Part III. 
increases in unbelievers, practitioners of non-Western religions, and adherents to postmodern spirituality now leave large numbers of Americans outside the boundaries of Judeo-Christianity. These demographic changes thus prevent Judeo-Christianity from performing the politically and socially unifying function of civil religion.

At the same time that religious demographic trends have expanded American religious diversity beyond the boundaries of Judeo-Christianity, political forces are contracting these same boundaries. ${ }^{13}$ Christian conservatives do not understand Judeo-Christianity as an inclusive manifestation of the religious beliefs of nearly all contemporary Americans, but rather as the historic and theologically exclusive faith of conservative Christianity. Consequently, the symbols and observances of Judeo-Christianity now signify the thicker sectarian meaning of this narrower religious interpretation of American history, and not the thin religiosity of civil religion. ${ }^{14}$ Although it is precisely the sectarian meaning of Judeo-Christian symbols and observances that motivates conservative Christians to defend their use by government, they ironically (if not cynically) rely on the historically thin religiosity of Judeo-Christianity to circumvent Establishment Clause limitations on such use. This "sectarianization" of JudeoChristianity excludes too many Americans for it to function as a unifying civil religion. "Sectarianization" also undermines the ethic of religious equality that now informs Establishment Clause jurisprudence, threatening a regression into classic tolerance, under which government would be constitutionally free to use the symbols and observances of a purportedly inclusive Judeo-Christian civil religion to promote conformity to a sectarian Christianity, so long as it protected the basic rights of unbelievers and adherents to other religious faiths.

The insistence of conservative Christians on retaining JudeoChristianity as the American civil religion creates social and political division, not unity. It has been the progressive separation of governmental machinery from thick conceptions of the good that has permitted liberal democracy to function in the United States despite radically different religious beliefs that exist among its citizens. ${ }^{15}$ Dramatically increasing religious pluralism in the United States, combined with the "sectarianization" of Judeo-Christianity, make it doubly unlikely that Judeo-Christianity or any civil religion can now function as a political and social unifier. Insistence on a democracy informed by Judeo-

13 See infra Part IV.

14 Throughout this Essay, we use "sectarian" to signify theological narrowness, exclusion, and self-absorption, and "nonsectarian" to signify the opposite-theological inclusion, ecumenicism, and openness. See, e.g., Steven D. Smith, Nonestablishment "under God"? The Nonsectarian Principle, 50 VILL. L. REV. 1, 7-8 (2005).

15 Throughout this Essay, we use "thick" in contrast to Rawls's "thin" theory of the good, which holds that contemporary liberal democratic societies should generally avoid imposing "thick" or substantive conceptions of the good on their members, in favor of "thin" or procedural conceptions that limit their protections to individual autonomy and do not presuppose any good beyond preservation of individual choice in a manner consistent with the rights of others. See infra note 145 and accompanying text. 
Christianity is thus precisely the wrong answer to the question of religious difference in the contemporary United States. ${ }^{16}$

\section{VARIETIES OF AMERICAN CIVIL RELIGION}

\section{A. The Established Church}

In eighteenth century Britain, the king's dual status as leader of the Church of England and head of the British state was thought essential to the maintenance of loyalty to crown and Parliament among British subjects. ${ }^{17} \mathrm{~A}$ similar understanding informed American government prior to the Revolution. ${ }^{18}$ Eight of the original thirteen colonies (and portions of a ninth) established a specific Protestant denomination by law, ${ }^{19}$ with the goal of developing and preserving popular loyalty to colonial law and government. ${ }^{20}$

\footnotetext{
16 See infra Part V.

17 E.g., William Warburton, The Alliance between Church and State (1736) (making the then-common argument that an alliance between civil government (prohibiting "open mischief") and religion (prohibiting "secret mischief") prevented Hobbesian anarchy); see FELDMAN, supra note 11, at 22 ("In England and on the European continent, in Catholic and Protestant countries alike, it had long been assumed that a close relationship between established religion and government was necessary to maintain social order and national cohesion."); Michael W. McConnell, Establishment and Disestablishment at the Founding, Part I: Establishment of Religion, 44 WM. \& MARY L. REV. 2105, 2114 (2003) (noting that the purpose of the Test, Corporation, and Conventicles Acts (among others) was in part to "retain the Queen's majesties subjects in their due obedience," by targeting Catholics and Puritans who were thought to threaten the political legiti-
} macy of the state (quotation omitted)).

18 See McConnell, supra note 17, at 2110-11.

19 Prior to the Revolution, the Church of England was officially established in Maryland, North Carolina, South Carolina, Georgia, and Virginia, as well as in portions of metropolitan New York. Additionally, each city or town in Connecticut, New Hampshire, and Massachusetts was authorized by law to select a locally established religion by majority vote; the overwhelming choice was Congregationalism. There was no established religion in Pennsylvania, Delaware, New Jersey, Rhode Island, and rural New York. Vermont also followed the New England model, though it was claimed by other colonies until well after the Revolution. Id.

20 See, e.g., FeldMAN, supra note 11, at 35; Gordon S. WoOd, THE Creation OF THE AMERICAN REPUBLIC 1776-1787, at 427-28 (2d ed. 1998); see also PhILIP HAMBURger, SEPARATION OF ChURCH AND STATE 107 (2002) (concluding that even early opponents of establishment in America acknowledged the importance of religion to government and never intended to create a constitutional doctrine that completely separated government from religion). Professor (now Judge) McConnell acknowledges that a pragmatic political stability underlaid the Anglican establishments, but argues that the Puritan and Congregationalist establishments in New England were grounded more "on the intense religious convictions of the people." McConnell, supra note 17 , at $2115-16$. 


\section{B. "Nonsectarian" Christianity}

Following the Revolution, the Establishment Clause of the First Amendment forbade the creation of a national church, ${ }^{21}$ which the substantial religious diversity of the newly formed American states would have precluded anyway. ${ }^{22}$ This same diversity also undermined state religious establishments, the last of which had disappeared by the $1830 \mathrm{~s} .{ }^{23}$ In their place arose "civil religion,"24 which linked American citizenship and loyalty to a "nonsectarian" Christian understanding that the United States has a divine origin and destiny. ${ }^{25}$ The tenets of this civil religion consisted of beliefs purportedly shared by all Christian religions, ${ }^{26}$ such as the existence of God, the literal truth of the Bible, the efficacy of prayer, and the expectation of an afterlife in which virtue is rewarded and vice is punished. ${ }^{27}$ Nonsectarian Christianity allowed the states to countenance close relationships between government and religion while simultaneously rejecting the idea of formal denominational establishments. ${ }^{28}$ Public schoolchildren were led in prayer and Bible-reading by government-paid teachers, ${ }^{29}$ public prayer became common in the state legislatures, ${ }^{30}$ important days of

21 U.S. CONST. amend. I, cl. 1 ("Congress shall make no law respecting an establishment of religion ...."); see also id, art. VI, cl. 3 ("[N]o religious Test shall ever be required as a Qualification to any Office or public Trust under the United States.").

22 In addition to the regional differences between Congregationalists and Puritans in New England and Anglicans in the South at the time of the Revolution, see supra note 18 and accompanying text, Rhode Island and certain communities in other of the newly independent states had been founded as havens for religious dissenters, and Baptist, Jewish, Presbyterian, and Quaker presences were evident throughout the country. See George Dargo, Religious Toleration and its Limits in Early America, 16 N. ILL. U. L. REV. 341, $352-53$ (1996); see also ANSON PHELPS StOKES, CHURCh AND STATE IN THE UNITED STATES 21-23 (1950) (noting the substantial religious diversity in colonial America); Thomas J. CurRy, The First FreEdoms: ChuRCh and STATE IN AMERICA TO THE PASSAGE OF THE FIRST AMENDMENT (1986) (documenting the same).

23 See Franklyn S. Haiman, Religious Expression and the American Constitution 6 (2003).

$24 \quad$ See supra text accompanying note 5 .

25 See BellaH, supra note 5, at 4 (observing that the "sacredness of the Constitution . . is closely bound up with the existence of the American people . . . .); id. at 27, 44 (arguing that Jefferson's invocation of the "laws of nature" in the Declaration and his use of biblical imagery captured the feelings of religious Americans about the United States and its destiny).

26 See FELDMAN, supra note 11, at 61.

27 See Robert N. Bellah, Beyond Belief: Essays on Religion in a Post-Traditional WORLD 171-72 (1970); see also John C. Jeffries, Jr. \& James E. Ryan, A Political History of the Establishment Clause, 100 MiCH. L. REv. 279, 297-98 (2001).

28 See FELDMAN, supra note 11, at 63, 81; HAMBURGER, supra note 20, at 275-84.

29 See FELDMAN, supra note 11, at 81; Jeffries \& Ryan, supra note 27, at 297-98.

30 See John Witte, JR., Religion AND the AMERICAN CONSTITUTIONAL EXPERIMENT 118 (2d ed. 2005); Steven B. Epstein, Rethinking the Constitutionality of Ceremonial Deism, 96 Colum. L. REV. 2083, 2104 (1996). 
Christian worship were recognized as civic holidays, ${ }^{31}$ biblical and other expressions of devotion to God appeared on government seals, documents, and buildings, ${ }^{32}$ and anti-blasphemy and Sunday-closing laws reinforced respect for the Christian God and the Christian Sabbath. ${ }^{33}$

\section{Judeo-Christianity}

Waves of European immigrants in the nineteenth and early twentieth centuries exposed "nonsectarian" Christianity as essentially Protestant. ${ }^{34}$ This period is accordingly marked by periodic Catholic and Jewish resistance to assimilation by "nonsectarian" Christian culture, ${ }^{35}$ especially in the public schools. ${ }^{36}$ By the 1950 s, however, these conflicts had largely abated. Succeeding generations of Catholic and Jewish immigrants had absorbed some of the Protestant individualism implicit in "nonsectarianism,"37 while nonsectarianism itself loosened its ties to Protestant beliefs and observances. ${ }^{38}$ This permitted a reformulation of the American civil religion from "nonsectarian" Christianity to a more plausible transdenominational "Judeo-Christianity." 39 Thus did Justice Douglas declare in the early 1950s that Americans are a "religious" rather than a

\footnotetext{
31 See WITTE, supra note 30 , at 118.

32 Id.; Epstein, supra note 30, at 2112-13.

33 See WITTE, supra note 30, at 118; Andrew J. King, Sunday Law in the Nineteenth Century,
} 64 ALB. L. REV. 675, 684-85 (2000).

34 See FELDMAN, supra note 11, at 12, 63-64; HAMBURGER, supra note 20, chs. 8, 10; see also Calvin Massey, The Political Marketplace of Religion, 57 HASTINGS L.J. 1, 11-12 (2005) (observing that in the late nineteenth century, "Protestant hegemony was preserved by using the political process to bar government aid to religious institutions regarded as mostly Catholic entities," and that "the only acceptable form of Christianity was some version of Protestantism").

35 See, e.g., FELDMAN, supra note 11, at 77 (describing Protestant "paranoia toward the Catholic church," and a "corresponding elevation of the Bible to the foundational text of American republicanism," based on the purported "connection among Bible reading, morality, and successful participation in republican government"); Thomas C. Berg, Minority Religions and the Religion Clauses, 82 WASH. U.L.Q. 919, 927 (2004) (describing Protestant discrimination against religious minorities, including Catholics and Jews, during the nineteenth century).

36 See, e.g., HAMBURGER, supra note 20, at 209-221 (relating intensification of tensions between Protestants and Catholics during the nineteenth century as the latter resisted the "nonsectarian" religion in the common schools and accused Protestants of religious intolerance).

37 See FELDMAN, supra note 11, at 90-91; HAMBURGER, supra note 20, at 207-09 ("Catholics in America increasingly felt individualistic expectations" and "adopted a liberalized, American understanding of their Church," which conceptualized papal authority as "merely of a spiritual nature" without power to "interfere with the temporal authority of our government.").

38 See Michael W. McConnell, Why Is Religious Liberty the "First Freedom"?, 21 CARDOzo L. REV. 1243, 1263-64 (2000).

39 See Feldman, supra note 11, at 91; Barbara L. Kramer, Reconciling Religious Rights \& Responsibilities, 30 LoY. U. CHI. L.J. 439, 440 n.10 (1999); Gerard V. Bradley, The Enduring Revolution: Law and Theology in the Secular State, 39 EMORY L.J. 217, 218 (1990) (book review). 
"Christian" people, and that American institutions presuppose belief in a "Supreme Being," which presumably signified the Jewish as well as the Christian God. $^{40}$

It was also in the 1950s that Will Herberg published his classic statement of American civil religion, Protestant-Catholic-Jew. ${ }^{41}$ Herberg argued that, unlike other immigrant characteristics like language or national origin, religious identity did not disappear into the "melting pot" of American assimilation. ${ }^{42}$ To the contrary, an immigrant entered the mainstream of American life precisely by retaining his or her religious identity-so long as it was Protestant, Catholic, or Jewish. "Unless one is either a Protestant, or a Catholic, or a Jew," Herberg argued, "one is a 'nothing'; to be a 'something,' to have a name, one must identify oneself to oneself, and be identified by others, as belonging to one or another of the three great religious communities in which the American people are divided." ${ }^{44}$ Noting that virtually all Americans identified themselves with one of these religious groups, ${ }^{45}$ Herberg concluded that Protestantism, Catholicism, and Judaism were each a quintessentially American religion and that "Judeo-Christianity" was thus the American civil religion. ${ }^{46}$

As Herberg explained, Judeo-Christianity built and maintained loyalty to the United States by linking certain transdenominational beliefs and observances of Protestants, Catholics, and Jews with patriotic fervor and national obligation. This function of Judeo-Christianity seemed particularly important at the height of the Cold War, in the face of the materialist and atheist threat of Soviet communism. ${ }^{47}$ Judeo-Christianity incorporated longstanding traditions, like government-sponsored prayer (especially in public schools), programs that permitted public school students to receive religious instruction during the normal school hours, and Sunday closing laws. To these it added belief in the divine origin and destiny of the United States, recognition of a transcendent morality shared by all Americans, faith in American democracy as the last, best safeguard of individual liberty, and recognition of a monotheistic God who

\footnotetext{
40 Compare Zorach v. Clauson, 343 U.S. 306, 313-14 (1952) ("We are a religious people whose institutions presuppose a Supreme Being.") with Church of the Holy Trinity v. United States, 143 U:S. 457, 471 (1892) ("“"[W]e are a Christian people, and the morality of the country is deeply ingrafted upon Christianity."') (quoting People v. Ruggles, 8 Johns. 290, 295 (N.Y. Sup. Ct. 1811)).

41 See HERBERG, supra note 10.

42 Id. at 40.

43 Id. at $53-54$.

44 Id.

$45 \quad$ Id. at 59.

46 Id. at 101 .

47 Stephen Bates, "Godless Communism" and Its Legacies, SOCIETY, Mar.-Apr. 2004, at 29 , 30; see Mark Silk, Notes on the Judeo-Christian Tradition in America, 36 AM. Q. 65, 69-70 (1984).
} 
gives America his special care and attention. ${ }^{48}$ These values were consistently affirmed in the 1950s, as in pledging allegiance to a nation "under God," 49 declaring "In God We Trust" as the national motto and requiring that it be imprinted on American coins and banknotes, ${ }^{50}$ erecting monuments and displays of the Ten Commandments, ${ }^{51}$ and invoking God and his blessing on America in political speeches and at other public events. ${ }^{52}$

In contrast to the ironic sectarianism of "nonsectarian" Christianity, 1950s Judeo-Christianity had greater potential to perform the socially unifying function of civil religion. As is evident from many of its symbols and practices, it was not so much theological common ground that made Judeo-Christianity viable as civil religion in the $1950 \mathrm{~s}$, but a narrow confluence of broader "spiritual" values that Protestants, Catholics, and Jews each supposedly placed at the foundation of American society.

Its inclusive potential notwithstanding, Judeo-Christianity did not function for very long as a unifying force in American society. The relative quiescence of the 1950s in the face of the Cold War was followed by the political and social upheavals of the 1960s and 1970s, which included constitutional invalidation of government use of many Judeo-Christian symbols and observances, particularly in the public schools. ${ }^{53}$ In reaction, numerous religious activist groups

48 See, e.g., HERBERG, supra note 10, at 52; see also Mirsky, supra note 6, at 1252 (identifying the five themes of American civil religion as belief in "some sort of transcendent principle of morality to which this polity is, or ought to be, responsible"; "faith in democracy as a way of life for all people and a concomitant belief in an American mission to spread it the world over"; "a sense of civic piety, that exercising the responsibilities of citizenship is somehow a good end in itself"; "reverence for American religious folkways"; and "a belief that Destiny has great things in store for the American people.").

49 See Act of June 14, 1954, Pub. L. No. 83-396, 68 Stat. 249 (codified as amended at 4 U.S.C. $\S 4$ (2007)).

50 See Act of July 11, 1955, Pub. L. No. 84-140, 69 Stat. 290 (codified at 31 U.S.C. § 5114 (b) (2007)) (mandating the inscription of "In God We Trust" on currency); Act of July 30, 1956, Pub. L. No. 84-851, 70 Stat. 732 (codified at 36 U.S.C. $\$ 302$ (2007)) (establishing "In God We Trust" as national motto).

51 See, e.g., Books v. City of Elkhart, 235 F.3d 292, 294 (7th Cir. 2000) (recounting origins of widespread distribution of decalogue monuments during the 1950 s by the Fraternal Order of the Eagles in response to a juvenile court judge's suggestion that the Commandments would supply young people with the moral code of conduct many of them apparently lacked), cert. denied, 532 U.S. 1058 (2001).

52 See, e.g., President Dwight D. Eisenhower, Inaugural Address (Jan. 20, 1953), available at http://www.presidency.ucsb.edu/ws/index.php?pid=9600 ("This faith . . . establishes, beyond debate, those gifts of the Creator that are man's inalienable rights, and that make all men equal in His sight . . . . It is because we, all of us, hold to these principles that the political changes accomplished this day do not imply turbulence, upheaval or disorder. Rather this change expresses a purpose of strengthening our dedication and devotion to the precepts of our founding documents, a conscious renewal of faith in our country and in the watchfulness of a Divine Providence.").

53 See, e.g., Stone v. Graham, 449 U.S. 39 (1980) (holding that public school display of decalogue violated Establishment Clause); Epperson v. Arkansas, 393 U.S. 97 (1968) (same with respect to ban on teaching any theory of human origin in public schools); Sch. Dist. of Abingdon 
emerged, primarily culturally and politically conservative Christians, ${ }^{54}$ whose goals included constitutional justification of the use by government of JudeoChristian symbols and observances. ${ }^{55}$ This coalition of conservative Christians grew and strengthened throughout the 1980s and 1990s, and entered the twentyfirst century with considerable social and political power. ${ }^{56}$

\section{BEYOND JUDEO-CHRISTIANITY}

Judeo-Christianity is still the American civil religion and continues to inform Establishment Clause doctrine, as the Decalogue Cases make clear. Trends in religious demographics, however, suggest that Judeo-Christianity can no longer plausibly claim to capture the beliefs of nearly all Americans and, correspondingly, that it can no longer plausibly claim to function as a socially and politically unifying civil religion.

\section{A. Unbelief and Eastern Religion}

Judging solely from Justice Scalia's rhetoric, ${ }^{57}$ one would think that the current number and devotion of American Protestants, Catholics, and Jews is

v. Schempp, 374 U.S. 203 (1963) (same with respect to public school-sponsored prayer and Biblereading); Engel v. Vitale, 370 U.S. 421 (1962) (same with respect to nondenominational government-composed prayer offered at the start of each school day); Torcaso v. Watkins, 367 U.S. 488 (1961) (same with respect to state requirement that notaries affirm belief in God).

54 See, e.g., FELDMAN, supra note 11, at 192-93 (describing the political influence and values agenda of Rev. Jerry Falwell's "Moral Majority" and Rev. Pat Robertson's "Christian Coalition" in the late 1970s and 1980s); Nancy T. Ammerman, Deep and Wide: The Real American Evangelicals, AM. INTEREST, Sept.-Oct. 2006, at 25, 30 (suggesting that conservative Christians were "propelled ... . into politics" by, inter alia, the "'moral breakdown' signaled by the Supreme Court's 1963 school prayer decision, its 1973 abortion decision, and the general upheaval of the proverbial Sixties").

For a succinct and insightful account of the political emergence of religious conservatism in the latter part of the Twentieth century, see KENNETH L. KARST, LAW's PROMISE, LAW's EXPRESSION ch.1 (1993).

55 See KARST, supra note 54, at 10, 148.

Some commentators have recently suggested that Christian conservatives themselves are now divided over many of these initiatives. See Russell Cobb, Cracks in the Christian Ascendancy, SlATE, June 27, 2006, available at http://www.slate.com/id/2144522; E.J. Dionne, Jr., A Shift Among the Evangelicals, WASH. POST, June 16, 2006, at A25, available at http://www.washingtonpost.com/wp-dyn/content/article/2006/06/15/AR2006061501790.html.

56 See, e.g., Bruce Ledewitz, Up Against the Wall of Separation: The Question of American Religious Democracy, 14 WM. \& MARY BILl RTS. J. 555 (2005) (arguing that conservative Christian influence on American politics has transformed the United States into a "religious democracy"). See generally Michelle GoldBERG, KINGDOM COMING: THE RISE OF ChRISTIAN Nationalism (2006); Kevin Phillips, American Theocracy: The Peril and Politics of Radical Religion, OIL, AND Borrowed MONEY IN THE 21st Century (2006); infra notes 116 120 and accompanying text.

57 See supra text accompanying notes $2-4$. 
virtually unchanged since the 1950 s, save only for the addition of a few Muslims. It is true, of course, that adherents to Buddhism, Hinduism, and other nonWestern or non-monotheistic religions still constitute less than two percent of all adult Americans. ${ }^{58}$ Emphasis on the small absolute number of such adherents, however, ignores their dramatic growth over the last half century. ${ }^{59}$ Moreover, Justice Scalia's decision to focus on monotheists as a percentage of the population of believers obscures the equally dramatic increase of unbelievers in the United States, now between ten and fifteen percent of the population, ${ }^{60} \mathrm{com}$ pared to three percent or less during the heyday of Judeo-Christianity. ${ }^{61}$

58 See, e.g., Barry A. Kosmin et al., GRaduate CENTER of the City Univ. OF N.Y., AMERICAN RELIGIOUS IDENTIFICATION SURVEY (2001) (reporting adult Muslim, Buddhist, Hindu, Baha'I, Taoist, and Sikh affiliation in 2001 at slightly over 3 million, or about $1.5 \%$ of the population), reprinted in U.S. CEnSUS BUREAU, STATISTICAL ABSTRACT OF THE UNITED STATES: 20042005, 2004, at 55; CIA, THE WORLD FACTBOOK 2007, http://www.cia.gov/library/publications/theworld-factbook/index.html (reporting American Muslim population at 1\% of the adult population, or approximately 3 million).

59 See Religions of AMERICA 196-97 (Leo Rosten, ed., 1955) (reporting that in 1953 Buddhists numbered only 63,000 or $0.04 \%$ of a population of about 95 million, and noting that Muslims were present in the United States but no statistical reports of their numbers were available); Stephen J. Stein, Religion/Religions in the United States: Changing Perspectives and Prospects, 75 IND. L.J. 37, 53-54 (2000) (detailing the "dramatic increase in the number of religious persons other than Christians and Jews in North America" during the latter part of the 20th century); see also Walter Russell Mead, God's Country?, ForEIGN AfF., Sept./Oct. 2006, at 24, 42 (noting the "growing presence and influence of non-Christian communities in the [United States]-of Jews, Muslims, Buddhists, [and] Hindus"); CIA, supra note 58 (reporting that $10 \%$ of the American population in 2002 reported themselves as affiliated with a religious denomination or sect that was neither Protestant, Roman Catholic, Mormon, Jewish, or Muslim); Harris Interactive Election 2000 Poll, http://www.adherents.com/rel_USA.html (reporting that $10 \%$ of a random 13,224 person sample of 5.6 million American registered voters identified through the Internet described themselves as affiliated with a religious denomination or sect that was neither Christian nor Jewish).

60 See, e.g., KoSMIN ET AL., supra note 58 (reporting that $14.1 \%$ of all adult Americans in 2001 described themselves as being atheist, agnostic, humanist, or secular, or as having no religion at all, and that an additional 5.4\% refused to specify a religious identification); GLENN H. UTTER \& James L. True, Conservative Christians and Political Participation 26 (2004) (concluding that "the largest percentage gain" reported in survey data between 1965 and 1996 "was in the secular category, which includes those stating no religious preference as well as respondents stating that they are atheists or agnostics," and which increased from $9.7 \%$ of survey respondents in 1965 to $16.3 \%$ of respondents in 1996); Harris Interactive Election 2000 Poll, supra note 59 (reporting that $7.1 \%$ of a random 13,224 person sample of 5.6 million American registered voters identified through the Internet described themselves as "agnostic" or "atheist," and that an additional $10 \%$ described themselves as "nonreligious" or refused to answer); see also U.S. CENSUS BUREAU, supra note 58, Table 67, at 55 (reporting that the number of self-identified unbelievers in 2001 had more than doubled since 1990); CIA, supra note 58 (reporting that in 2002, 10\% of Americans declined to identify themselves as members of any religious denomination); Ammerman, supra note 54, at 27 (observing that "nearly 20 percent of the [American] population never goes anywhere religious at all").

The recent study conducted by the Baylor Institute for Studies of Religion suggests that only 4\% of Americans are nonbelievers. See BAYLOR INSTITUTE FOR STUDIES OF RELIGION, AMERICAN PIETY IN THE 21st CENTURY 8, 12 (2006) [hereinafter BAYLOR InSTITUTE], available at 


\section{B. Spirituality}

Additionally, a turn towards "spirituality" has arisen among American believers within the last twenty years. This is a new attitude of belief that cannot properly be characterized as either predominantly secular or traditionally religious. ${ }^{62}$ Spirituality is characterized by personal choice-by adherence to a faith or religion based on the individual needs it satisfies, rather than the truthclaims it makes or the conversion experience it may generate. ${ }^{63}$ Spirituality incorporates the consumer mentality of a marketplace in which believers shop for beliefs and practices, picking and choosing from among diverse and even incompatible denominations and traditions. ${ }^{64}$ Whereas the principal focus of traditional denominational religion is on revelation of a reality beyond the tem-

http://www.baylor.edu/content/services/document.php/33304.pdf (reporting that 10.8\% of Americans are not affiliated with a "congregation, denomination, or other religious group," but that $62.9 \%$ of these nevertheless "believe in God or some higher power"); see also Where We Stand on Faith, NewsweEk, Sept. 5, 2005, at 48 (reporting that only 6\% of Americans describe themselves as "atheist," "agnostic," or having "no religion," and that only an additional $4 \%$ declined to answer). It is not clear, however, that the "belief" of this group extends significantly beyond agnosticism. See BAYLOR INSTITUTE, supra, at 14 (reporting that overwhelming majorities of religiously unaffiliated Americans "never" attend weekly services, pray, or read scripture, and reject the Bible as the word of God); cf. infra notes 69-72 and accompanying text (arguing that the object of faith for many who are routinely classified as monotheistic "believers" is not recognizable as the traditional God of American monotheism).

61 George Gallup, American Institute of Public Opinion (Jan. 9, 1948) (reporting that only 3\% of Americans disclaimed belief in God, and only 3\% expressed uncertainty about such belief), reprinted in RELIGIONS OF AMERICA, supra note 59, at 247; George Gallup, American Institute of Public Opinion (Dec. 9, 1944) (reporting that only 1\% of Americans identified themselves as not believing in God, and only $5 \%$ as undecided), reprinted in, RELIGIONS OF AMERICA, supra note 59, at 237.

The rate of unbelief is also three times as great among the young as the old. See, e.g., Where We Stand on Faith, supra note 60 (reporting in 2005 that $9 \%$ of those age 18 to 39 describe their religion as "atheist," compared to $3 \%$ of those age 60 or older); cf. BAYLOR INSTTTUTE, supra note 60 , at 9 (reporting in 2006 that $18.6 \%$ of those age 18 to 30 declared no religious affiliation, compared to $5.4 \%$ of those age 65 or older). While this might indicate that the proportion of unbelievers in the United States will continue to grow, any such growth would be blunted or perhaps neutralized altogether by unbelievers who return to religion as they age and approach death.

62 See, e.g., Stein, supra note 59, at 58 (observing that contemporary religion "is increasingly likely to be defined as any system of belief or practices resembling" denominational religion, and that "a growing number of Americans . . . completely reject the word 'religious' and in its place use the word "spiritual"').

63 For a detailed discussion of postmodern spirituality, see Frederick Mark Gedicks, Spirituality, Fundamentalism, Liberty: Religion at the End of Modernity, 54 DEPAUL. L. REV. 1197, 121519 (2005).

64 See, e.g., Rebecca French, Shopping for Religion: The Change in Everyday Religious Practice and its Importance to the Law, 51 BUFF. L. REV. 127 (2003); see also Stein, supra note 59, at 57 (arguing that "[d]enominational categories are no longer sufficient or primary religious identifiers for many contemporary Americans"). 
poral self, the emphasis of spirituality is on revelation of that very self. ${ }^{65} \mathrm{Be}$ tween $20 \%$ and $25 \%$ of Americans identify themselves as "spiritual but not religious." $" 66$

There is undoubtedly some overlap among the categories of unbelief and non-Western and non-monotheistic religion, on the one hand, and spirituality, on the other, so that one cannot simply add the percentages representing these categories together to calculate a percentage of Americans who find themselves outside of the Judeo-Christian mainstream. The number of adherents to spirituality, for example, almost certainly includes some who would describe themselves as either nonbelievers or followers of eastern religions. ${ }^{67}$ Similarly, such adherents also undoubtedly include members of Christian denominations whose spiritual understanding of their faith would not be acceptable to more orthodox members. ${ }^{68}$ Nevertheless, the overlap is not total一that is, one cannot assume that all of the "spiritual but not religious" would classify themselves as unbelievers, followers of a non-Western or non-monotheistic religion, or members of a Christian denomination; some, for example, might classify themselves as believers unaffiliated with any religious tradition.

\section{Barely Believing}

Finally, postmodern sensibilities have eroded even traditional denominational understandings of "God" and belief. One effect of the postmodern spirituality movement has been a shift away from denominational Christianity and the truth of its doctrines, even among members of some traditionally conservative denominations. ${ }^{69}$ A substantial minority of American believers, for example, recall the Enlightenment deists, describing their object of faith as a "distant" God who "sets the laws of nature in motion," is unconcerned about

65 Gedicks, supra note 63 , at 1219 ; see, e.g., AlAN Wolfe, THE Transformation of AMERICAN RELIGION 182-84 (2003) (describing spirituality as a "blending of psychology and religion" that avoids traditional notions of sin and duty and focuses on concepts of self-esteem and personal growth); Ira C. Lupu \& Robert Tuttle, The Distinctive Place of Religious Entities in Our Constitutional Order, 47 VILL. L. REv. 37, 67 (2002) ("At the time of the Framing, religion, for many Americans, was a source of comprehensive understanding about Divine Providence and the order of the universe. The rise of science, technology, psychoanalysis, and other profoundly secularizing influences, however, has altered perceptions about the role of religion. For many Americans, religion is now affective, psychological, and interior.").

66 Where We Stand on Faith, supra note 60 (emphasis added). Regrettably, the Baylor Institute study did not include questions about postmodern spirituality. See BAYLOR INSTITUTE, supra note 60, App. B (listing survey questions used in the study).

67 See Massey, supra note 34, at 18 (noting "considerable overlap" between spirituality and psychology, and observing that practitioners of spirituality often combine the metaphysics of eastern religions with psychology).

68 See Gedicks, supra note 63, at 1216, 1218.

69 Gedicks, supra note 63, at 1216-18; e.g., Charles Trueheart, Welcome to the Next Church, ATLANTIC MONTHLY, Aug. 1996, at 37 (describing the evangelical megachurch movement). 
human activities, and does not intervene in earthly events. ${ }^{70}$ Some members of the Protestant mainline-American Baptists, Congregationalists, Episcopals, Lutherans, Methodists, and Presbyterians-are skeptical about the divinity of Jesus, oppose literal-historical understandings of the Bible, and reject Jesus's miracles, including the resurrection. ${ }^{71}$ Such trends are even evident among evangelical Protestants; large numbers of teenage evangelicals, for example, do not believe in the resurrection and reject the idea of absolute truth, believing that "all religious faiths teach equally valid truths."72 These postmodern beliefs seem to be positioned equidistant between traditional Christian belief and agnosticism; at the least, the disconnected and atheological "God" of postmodern believers bears little resemblance to the omniscient and omnipotent "God" of the Judeo-Christian tradition.

It is not clear that 1950 s Judeo-Christianity was ever as broad and inclusive as it claimed to be, particularly with respect to non-Christians like Jews and marginalized Christians like Adventists, Jehovah's Witnesses, and Mormons. The dramatic growth of unbelief and religious pluralism generally has rendered the breadth of Judeo-Christianity even more problematic. One can reliably estimate that between one-quarter and one-third of Americans no longer fall within the traditional denominational definitions of Protestant, Catholic, or Jew. Even if one adds Islam to create a marginally larger "Abrahamic" monotheism, ${ }^{73}$ it remains that at least a quarter of Americans adhere to religions or religious beliefs that would place them outside the orthodox boundaries of even this reformulation, or do not believe in a god at all. Even among the American majority touted by Justice Scalia as "monotheistic believers," traditional faith in a traditional God is often absent.

70 BAYLOR INSTITUTE, supra note 60 , at 27, 29 (reporting that $24.4 \%$ of Americans believe in such a God).

71 Mead, supra note 59, at 30; see also id. at 31 (describing the Protestant mainline as having a "lower estimate of the difference between Christians and non-Christians than do the other major forms of American Protestantism," and attaching little importance to the "idea of the church as a supernatural society whose members enjoy special grace").

72 See Dale Buss, Christian Teens? Not Very, Wall ST. J., Jul. 9, 2004, at W13 (reporting findings of evangelical youth minister Josh McDowell that $91 \%$ of born-again teenage evangelicals do not believe in absolute truth, that a "slight majority" reject the resurrection, and that nearly $60 \%$ believe that "all religious faiths teach equally valid truths"). Rev. McDowell's website suggests that his conclusions were drawn from findings of the Barna Research Group. See Josh McDowell, Teen Statistics, http://www.josh.org/notes/file/Internet 16-TeenStatistics.pdf (citing Barna Research Group, Americans Are Most Likely to Base Truth on Feelings (Feb. 12, 2002), available at http://www.barna.org/FlexPage.aspx?Page=BarnaUpdate\&BarnaUpdateID=106).

73 See, e.g., McCreary County v. ACLU, 545 U.S. 844, 893-94 (2005) (Scalia, J., dissenting) (arguing that government acknowledgment of the nondenominational monotheistic God of Christianity, Islam, and Judaism does not constitute an establishment of religion); see also Van Orden v. Perry, 545 U.S. 677, 687, 690 (2005) (Rehnquist, C.J., plurality) (same with respect to government invocation of "God" and the "Judeo-Christian belief"). 


\section{THE "SECTARIANIZATION" OF JUDEO-CHRISTIANITY}

Demographically, the United States is now well beyond the point where the symbols and practices of either a "Judeo-Christian" or an "Abrahamic" civil religion can authentically represent the religious commitments of all or nearly all Americans. Even more problematic for Judeo-Christianity is a cultural counter-revolution of conservative Christians seeking to narrow the meaning of Judeo-Christian symbols and practices, even as increasing numbers of unbelievers and less orthodox believers already find themselves outside the traditionally broad meaning associated with such symbols and practices.

\section{A. The Decalogue Cases}

During the night of July 31, 2001, Roy Moore, then the Chief Justice of the Alabama Supreme Court, arranged for the installation of a two and one-half ton granite representation of the Ten Commandments in a prominent location in the Alabama state courthouse. ${ }^{74}$ The installation was filmed by the Coral Ridge Baptist Church, but no members of the media were present or, apparently, invited. $^{75}$ In a dedicatory speech the next day, Chief Justice Moore left no doubt that the monument symbolized the sovereignty of God over the state as well as the church. Referring to quotations from secular historical sources carved on the sides of the monument below the focal representation of the Commandments, Chief Justice Moore declared that the monument displayed

every ounce of support for the acknowledgment of the sovereignty of . . . God and those absolute standards upon which our laws are based. Oh, this isn't surrounding the plaque with history, historical documents. All history supports the acknowledgment of God. You'll find no documents surrounding the Ten Commandments because they stand alone as an acknowledgment of that God that's contained in our pledge, contained in our motto, and contained in our oath. ${ }^{76}$

Elsewhere in this speech and in his trial testimony during subsequent litigation, Moore made clear that the "God" to which he referred was the God of JudeoChristian civil religion. ${ }^{77}$

\footnotetext{
74 See Glassroth v. Moore, 229 F. Supp. 2d 1290, 1294 (M.D. Ala. 2002), affd, 335 F.3d 1282 (11 th Cir. 2003).

75 Id. at 1294.

$76 \quad$ Id. app. C., at 1324.

77 Id. at 1299 (summarizing Chief Justice Moore's trial testimony that "the Judeo-Christian God reigned over both the church and the state in [the United States] and that both owed allegiance to that God"); e.g., id. app. C., at 1323 (copy of Moore's dedicatory speech) ("Today a cry has gone out across our land for the acknowledgment of that God upon whom this nation and our laws were founded and for those simple truths which our forefathers found to be self-evident; but
} 
Chief Justice Moore's unapologetically Judeo-Christian defense of the placement of a conspicuous religious monument in the state courthouse triggered more than two years of hard-fought litigation, ${ }^{78}$ together with intense media coverage and public demonstrations. ${ }^{79}$ The controversy ended in the removal of the monument from the courthouse as a violation of the Establishment Clause and the removal of Moore as Chief Justice of Alabama for defying a federal court order to remove the monument.

Moore's effort to defend government sponsorship of a sectarian display of the Ten Commandments is not an isolated incident. In the last few years, other lower court decisions have examined other decalogue monuments apparently erected with comparable sectarian motivations, ${ }^{80}$ and the United States

once again, we find that those cries have fallen upon eyes that have seen not, ears that hear not our prayers, and hearts much like that nether millstone."); see also id. app C., at 1322- 24 (quoting and summarizing references to "God" in or by the preamble to the Alabama Constitution; McGowan v. Maryland, 366 U.S. 420, 562-63 (1961); the Declaration of Independence; the 1954 revision of the Pledge of Allegiance; Samuel Adams; James Madison; William Blackstone; George Washington; the "Star-Spangled Banner;" the national motto; executive, judicial, and legislative oaths of office; John Jay; and Thomas Jefferson).

78 See id.; see also Glassroth v. Houston, 299 F. Supp. 2d 1244 (M.D. Ala. 2004) (granting substitution of Senior Associate Justice of Alabama Supreme Court as defendant in Moore's place following Moore's removal as Chief Justice and denying Moore's motion that such Justice recuse himself from participation in the litigation); Glassroth v. Moore, 278 F. Supp. 2d 1272 (M.D. Ala. 2003) (denying Moore's motion for stay of final judgment and entrance of injunction pending action on petition for review by Supreme Court); Glassroth v. Moore, 275 F. Supp. 2d 1347 (M.D. Ala. 2003) (entering final judgment and permanent injunction against Moore on remand from Court of Appeals); Glassroth v. Moore, 242 F. Supp. 2d 1067 (M.D. Ala. 2002) (granting motion that court enter permanent injunction and order removal of monument after Moore failed to do so voluntarily following court's prior decision that monument violated Establishment Clause); Glassroth v. Moore, 229 F. Supp. 2d 1283 (M.D. Ala. 2002) (denying Moore's motion that district judge recuse himself for bias against Moore); Moore v. Judicial Inquiry Comm'n., 891 So.2d 848 (Ala. 2004) (affirming Commission order removing Moore as Alabama Chief Justice for failure to obey federal court orders).

79 See, e.g., Jeffrey Gettleman, Supporters of Ten Commandments Rally On, N.Y. TimES, Aug. 24,2003 , at $\mathrm{N} 20$.

80 See, e.g., Adland v. Russ, 307 F.3d 471, 476 (6th Cir. 2002) (2-1 decision) (invalidating large state-sponsored Commandments monument surrounded by quotes of famous Americans "professing their beliefs in the Bible, God, or Christianity," a quote from a Supreme Court decision declaring the United States to be a "Christian nation," and containing two "Stars of David and the Chi rho symbol"), cert. denied, 538 U.S. 999 (2003); Turner v. Habersham County, 290 F. Supp. 2d 1362 (N.D. Ga. 2003) (invalidating county-sponsored plaque of King James version of the "Ten Commandments of Almighty God," where county resolution stated that Commandments were posted "in consideration of our biblical history of Georgia, both in our constitution and devotional acts in our heritage," and for the purpose of petitioning "the God of Heaven to preserve the peace which he has so graciously extended to [us] by our ancient acknowledgment of the Ten Commandments," and begging God's "continued protection and alleviation of ills which come to those who forget him and his law") (emphasis omitted); ACLU v. Hamilton County, 202 F. Supp. 2d 757, 764 (E.D. Tenn. 2002) (invalidating county-sponsored plaque containing King James version of the Commandments, where motivation of county commissioner who sponsored authorizing legislation was to "have copies of 'God's law posted all over [the] county"'). 
Supreme Court has recently reviewed three decalogue displays and monuments, two of which had an origin and history similar to those of Moore's Alabama monument.

Two displays were reviewed by the Supreme Court in McCreary County v. ACLU of Kentucky. ${ }^{81}$ Both involved the hanging of "large, goldframed copies" of an abridgment of the "King James version of the Commandments," complete with citation to Exodus, in a prominent place in a county courthouse accompanied by explicitly religious or Christian endorsements. ${ }^{82}$ In response to legal challenges under the Establishment Clause, both counties added smaller displays of excerpts from secular documents that referred to God, religious symbols, or observances, including the Declaration of Independence, the Preamble to the Kentucky Constitution, the national motto, a congressional proclamation declaring 1983 as the "Year of the Bible," a proclamation by President Lincoln declaring a "National Day of Prayer and Humiliation," a quotation by President Lincoln identifying the Bible as "the best gift God has ever given to man," and the Mayflower Compact. ${ }^{83}$ These additions were ordered by county resolutions that expressly invoked Moore's arguments in defense of his Alabama monument, called Jesus the "Prince of Ethics," and appealed to a purported belief of the founders that government officials were obligated " to publicly acknowledge God as the source of America's strength and direction.", 84 The Court declared these displays unconstitutional under the Establishment Clause for lack of a secular purpose. ${ }^{85}$

Contemporaneous with its review of the decalogue displays in McCreary County, the Court reviewed another such display in Van Orden v. Perry ${ }^{86}$ This display is a large stone monument of the King James version of the Commandments located on the grounds of a State Capitol among numerous secular and historical monuments. ${ }^{87}$ The monument is one of hundreds that the Fraternal Order of the Eagles donated to state and local governments in the 1950 s to encourage juveniles to refrain from anti-social behavior. ${ }^{88}$ In addition to the Commandments, the monument also contains representations of "[a]n eagle grasping the American flag," a pyramidal all-seeing eye, "two stars of

\footnotetext{
81545 U.S. 844 (2005).

$82 \quad I d$. at 851.

$83 \quad$ ld. at $853-54$.

84 Id. at 853 (quoting exhibits). These displays were altered yet a third time in the course of this litigation, by removing the other document displays and adding for display along with the Commandments equal-sized representations "of the Magna Carta, the Declaration of Independence, the Bill of Rights, the lyrics to the Star Spangled Banner, the Mayflower Compact, the National Motto, the Preamble to the Kentucky Constitution, and a picture of Lady Justice," together with a statement of the "historical and legal significance" of each such document. Id. at 856.

$85 \quad I d$. at 868-70.

$86 \quad 545$ U.S. 677 (2005).

$87 \quad$ Id. at 681 (plurality opinion).

88 See id. at 682 (plurality opinion); id. at 701 (Breyer, J., concurring).
} 
David, and the two superimposed Greek letters Chi and Rho, which traditionally signify Christ. $^{89}$ In a decision that did not yield a majority opinion, the Court rejected an Establishment Clause challenge to the monument on the apparent ground that the context in which the monument appeared suggested secular as well as religious purposes. ${ }^{90}$

\section{B. The Fiction of "Mere Acknowledgment"}

The characteristic religious motivation for public decalogue exhibits contrasts sharply with the manner in which their constitutionality is defended against Establishment Clause challenges. One of the standard rhetorical moves of those who defend government appropriation of Judeo-Christian symbols and practices is deemphasis of their theological content and contemporary religious significance. $^{91}$ Supreme Court opinions defending government deployment of Judeo-Christian symbols and observances consistently characterize them as historical, passive, generic, and innocuous. ${ }^{92}$ The Decalogue Cases are no excep-

\footnotetext{
$89 \quad I d$. at 681 (plurality opinion).
}

90 Id. at 691-92 (plurality opinion) (arguing that because the state "has treated its Capitol grounds monuments as representing the several strands in the State's political and legal history," the setting "of the Ten Commandments monument in this group has a dual significance, partaking of both religion and government"); id. at 701-02 (Breyer, J., concurring) (arguing that the placement of the disputed decalogue monument in a "large park containing 17 monuments and 21 historical markers" illustrates "a relation between ethics and law that the State's citizens, historically speaking, have endorsed," and thus communicates "a . . . secular [moral] message" about proper standards of social conduct").

91 Professor Gedicks has elaborated this point in FrEDERICK MARK GEDICKS, THE RHETORIC OF ChURCH AND STATE 74-80 (1995). See also KARST, supra note 54, at 154-55 (describing but not endorsing arguments that government use of Judeo-Christian symbols does not violate the Establishment Clause because such use is a "de minimus endorsement of religion, has a long historical pedigree, and is passive and noncoercive); Epstein, supra note 30, 2164-65 ("Another popular argument used to justify the constitutional permissibility of ceremonial deism is that through rote repetition, transformations which have occurred over time, and the emergence of secular and patriotic traditions associated with religious holidays, these practices have lost whatever religious significance they may once have had."); Alexandra Furth, Comment, Secular Idolatry and Sacred Traditions: A Critique of the Supreme Court's Secularization Analysis, 146 U. PA. L. REv. 579, 591-92 (1998) ("Where a practice or symbol is perceived as integral to American culture, or where the context of a display which includes religious articles creates an impression of mere holiday celebration or religious pluralism, the symbols will be recharacterized as secular."); Steven G. Gey, "Under God," The Pledge of Allegiance, and other Constitutional Trivia, 81 N.C. L. REV. 1865, 1905 (2003) (noting the common argument that " 'God' in the context of the Pledge is not a sufficiently religious concept to implicate the protections of the Establishment Clause").

92 See, e.g., County of Allegheny v. ACLU, 492 U.S. 573, 616 (1989) (conceding religious significance of Jewish menorah, but arguing that it also signifies a secular cultural tradition akin to Christmas and that both Christmas and Chanukah are secular symbols of the same "winterholiday" season); Lynch v. Donnelly, 465 U.S. 668, 685 (1984) (characterizing nativity scene as passive commemoration of the historical origins of Christmas, and promoting friendship and a means of promoting "a friendly community spirit of goodwill"); McGowan v. Maryland, 366 U.S. 420 (1961) (characterizing Sunday closing laws as promoting rest, relaxation, recreation, community, and family togetherness, rather than church attendance or Sabbath observance); see also Elk 
tion. The Van Orden plurality, for example, minimizes the religious significance of the monument at issue in that case by repeatedly characterizing it as a mere passive "acknowledgment" of the religious history and heritage of the United States. $^{93}$ Individual opinions in both McCreary County and Van Orden follow the same pattern. ${ }^{94}$

The theme of these opinions is that displays of the Commandments constitute only the faintest recognition of a nonsectarian God. Decalogue displays, in other words, purportedly symbolize nothing more than ecumenical, transdenominational belief. The implication is that objections to such a benign and innocuous symbolic meaning betray an unreasonable hostility to religion. ${ }^{95}$ In

Grove Indep. Sch. Dist. v. Newdow, 542 U.S. 1, 26, 31 (2004) (Rehnquist, C.J., concurring in judgment) (arguing that "under God" in the Pledge of Allegiance is neither an expression nor an endorsement of religious belief but merely acknowledges that the United States was founded on belief in God); Santa Fe Indep. Sch. Dist. v. Doe, 530 U.S. 290, 322, 324 (2000) (Rehnquist, C.J., dissenting) (arguing that prayer by a peer-selected student before high school football games solemnized the game, promoted sportsmanship and safety, and created a proper competitive environment, and speculating that students might choose those giving prayers on the basis of public speaking ability or social standing rather than religion).

93545 U.S. 677, 688 (2005) (plurality opinion) (Monuments and other official government "acknowledgments of the role played by the Ten Commandments in our Nation's heritage are common throughout America."); accord id. at 683 ("Our cases, Januslike, point in two directions in applying the Establishment Clause. One face looks toward the strong role played by religion and religious traditions throughout our Nation's history ... . The other face looks toward the principle that governmental intervention in religious matters can itself endanger religious freedom .... One face looks to the past in acknowledgment of our Nation's heritage, while the other looks to the present in demanding a separation between church and state."); id. at 686 (plurality opinion) (characterizing the Lemon test as "not useful in dealing with the sort of passive monument that Texas has erected"); id. at 689 (plurality opinion) ("Our opinions, like our [Supreme Court] building have recognized the role the Decalogue plays in America's heritage."); $i d$. at 691 (plurality opinion) ("The placement of the Ten Commandments monument on the Texas State Capitol grounds is a far more passive use of those texts than was the case in Stone [v. Graham], where the text confronted elementary school students every day.").

94 See id. at 692 (Scalia, J., concurring) ("[T]here is nothing unconstitutional in a State's favoring religion generally, honoring God through public prayer and acknowledgment, or, in a nonproselytizing manner, venerating the Ten Commandments."); id. at 692 (Thomas, J., concurring) (The plurality "properly recognizes the role of religion in this Nation's history and the permissibility of government displays acknowledging that history."); id. at 694 (Thomas, J., concurring) ("The mere presence of the monument [on the capitol grounds] involves no coercion and thus does not violate the Establishment Clause."); id. at 694 (Thomas, J., concurring) (characterizing the Judeo-Christian symbols reviewed by the Court "benign signs and postings"); McCreary County v. ACLU, 545 U.S. 844, 892 (2005) (Scalia, J., dissenting) ("Why, one wonders, is not respect for the Ten Commandments a tolerable acknowledgment of beliefs widely held among the people of this country?"); id. at 894 (Scalia, J., dissenting) ("Historical practices thus demonstrate that there is a distance between the acknowledgment of a single Creator and the establishment of a religion."); id. at 905 (Scalia, J., dissenting) ("The acknowledgment of the contribution that religion in general, and the Ten Commandments in particular, have made to our Nation's legal and governmental heritage is surely no more of a step toward the establishment of religion than was the practice of legislative prayer ....").

95 Cf. Gey, supra note 91 , at 1914 (noting and criticizing the common observation that the only people upset by "trivial" government establishments like "In God We Trust" on coins or 
this view, official government recognition of the Ten Commandments is like the polite nod one gives to an acquaintance passing on the street. This rhetoric of "mere acknowledgment" ignores that the symbols and practices of JudeoChristian civil religion are widely perceived as religious, Christian, and sectarian, having little to do with contemporary secular law.

\section{Religious Meaning}

The religious content of the Ten Commandments can hardly be gainsaid. ${ }^{96}$ The Commandments prohibit, among other things, unbelief, polytheism, the worship of icons and images, blasphemy, coveting, Sabbath-breaking, parental disrespect, and adultery. These are attitudes and actions that would not--and could not--be criminalized under contemporary constitutional jurisprudence. ${ }^{97}$ Only the prohibitions on murder, theft, and perjury have a secular content that is fairly reflected in contemporary law. ${ }^{98}$

"under God" in the Pledge are "hypersensitive religious spoilsports") (discussing Newdow v. United States Congress, 292 F.3d 597, 613 (9th Cir. 2002) (Fernandez, J., concurring in part and dissenting in part), rev'd on other grounds sub. nom. Elkgrove Indep. Sch. Dist. v. Newdow, 542 U.S. 1 (2004)); Newdow, 292 F.3d at 613 (Fernandez, J., concurring in part and dissenting in part) ("[S]uch phrases as "In God We Trust" or "under God" have no tendency to establish a religion in this country or to suppress anyone's exercise, or non-exercise, of religion, except in the fevered eye of persons who most fervently would like to drive all tincture of religion out of the public life of our polity."); c.f. Timothy Hall, Sacred Solemnity: Civic Prayer, Civil Communion, and the Establishment Clause, 79 IowA L. Rev. 35, 86 (1993) ("Justice Scalia implicitly assumes that anyone who cannot endure an innocuous civic prayer is simply a bigot.") (discussing the graduation prayer at issue in Lee v. Weisman, 505 U.S. 577, 631 (1992) (Scalia, J., dissenting)).

96 See Epstein, supra note 30, at 2165 ("'[U]nder any honest appraisal of modern American society, the practices constituting ceremonial deism have not lost their religious significance."); $c f$. Timothy Zick, Cross Burning, Cockfighting, and Symbolic Meaning: Toward a First Amendment Ethnography, 45 WM. \& MARY L. REV. 2261, 2297 (2004) (arguing that in the creche cases the Court was "indifferent" to the "constitutive meaning sacred symbols have for those who truly believe in them") (discussing County of Allegheny, 492 U.S. 573 (1989); Lynch v. Donnelly, 465 U.S. 668 (1984)).

97 See Stone v. Graham, 449 U.S. 39, 42 (1981) (observing that decalogue prohibitions on polytheism, idolatry, blasphemy, and Sabbath-breaking specify "religious duties of believers"); Arnold H. Lowey, Morals Legislation and the Establishment Clause, 55 ALA. L. REv. 159, 16266 (2003) (arguing that government enforcement of decalogue prohibitions on disbelief in the monotheistic God, making graven images of God, blasphemy, and coveting would clearly violate the Establishment Clause, and that such enforcement of decalogue prohibitions on Sabbathbreaking, parental disrespect, and adultery would avoid violating the Clause only in particular circumstances).

98 See Lowey, supra note 97, at 162; see also Stone, 449 U.S. at 41-42 (observing that only the prohibitions on honoring one's parents, murder, adultery, theft, perjury, and coveting are "arguably secular"). 


\section{Christian Meaning}

The meaning symbolized by decalogue displays is not just religious but also Christian. As the context of these displays inevitably makes clear, displaying the Commandments is usually about honoring the Christian God. ${ }^{99}$ It is almost always a Christian majority that seeks to impose Judeo-Christian symbols and observances on the community, ${ }^{100}$ even when, like the decalogue displays, these take the form of a Jewish text or symbol. ${ }^{101}$ It is no accident that both Jewish members of the Court voted to invalidate the overtly Christian displays in $\mathrm{McCreary}$ County that Justice Scalia and other conservative Justices would have upheld, ${ }^{102}$ and that one of these same Justices also dissented from the Court's constitutional validation of the less religiously charged monument in Van Orden. ${ }^{103}$

In fact, Judeo-Christianity is far more congenial to the beliefs of Christians than it is to those of Jews. Because conventional Christian theology generally characterizes Judaism as a proto-Christianity that was "completed" or "fulfilled" with Jesus and the resurrection, ${ }^{104}$ Christians can incorporate Judaism into their faith in a way that Jews cannot incorporate Christianity into theirs. ${ }^{105}$

\footnotetext{
99 See supra notes 74-90 and accompanying text.
}

100 See, e.g., Santa Fe Indep. Sch. Dist. v. Doe, 530 U.S. 290 (2000) (school sponsored prayers delivered by evangelical Protestant students at high school football games); County of Allegheny v. ACLU, 492 U.S. 581 (1989) (government sponsored Christmas nativity scene); Lynch v. Donnelly, 465 U.S. 668 (1984) (same); Braunfeld v. Brown, 366 U.S. 599 (1961) (Sunday closing law); see also Furth, supra note 91, at 604 (observing that symbols of civil religion whose use by government is defended because of their purportedly "secularized" character are usually Christian). But see Lee v. Weisman, 505 U.S. 577 (1992) (government sponsored prayer delivered by Jewish rabbi at junior high school graduation).

101 See, e.g., Allegheny, 492 U.S. 581 (1989) (government sponsored display of Christmas tree with Jewish menorah); Edwards v. Aguillard, 482 U.S. 578 (1987) (state law mandating the teaching of creationism together with Darwinism in public schools to balance that latter's challenge to literal readings of Genesis creation story); Epperson v. Arkansas, 393 U.S. 97 (1968) (state law prohibiting the teaching of Darwinism in public schools because of challenge to literal readings of Genesis creation story).

102 See 545 U.S. 844, 848 (noting that Ginsburg \& Breyer, JJ., joined the majority opinion of Souter, J.); compare KARST, supra note 54, at 157 (noting that the authors of the two main dissents to a Ninth Circuit opinion upholding state recognition of Good Friday as an official holiday were, respectively, Baha'I and Jewish).

103 See 545 U.S. 677, 707, 737 (noting that Ginsburg, J., joined the dissenting opinions of Stevens \& Souter, JJ., respectively).

104 See, e.g., Arthur A. Cohen, The Myth of the Judeo-Christian Tradition 55-56, 69-70 (1970); see also JOAN DELFATTORE, THE FOURTH R: CONFLICTS OVER RELIGION IN AMERICA'S PUBLIC SCHOOLS 312 (2004) ("Islam has an analogous attitude towards Christianity, which makes it unlikely that any sort of 'Abrahamic' tradition drawn from Judaism, Christianity, and Islam could effectively succeed Judeo-Christianity as a unifying American civil religion.”).

105 See Mark V. Tushnet, The Conception of Tradition in Constitutional Historiography, 29 WM. \& MARY L. REV. 93, 94 n.6 (1987) ("I had thought that the Judeo-Christian tradition was actually a Christian tradition; that is, only Christians can describe a Judeo-Christian tradition 
To the extent that the "Judeo-Christian" tradition symbolizes essential Christian beliefs, its symbolism obviously and necessarily excludes Jews. Notwithstanding its name, "Judeo-Christianity" is essentially a Christian tradition whose symbols and observances include a symbolic meaning that Jews do not accept.

As Christians ourselves, we obviously cannot speak for Jews or other non-Christian minorities. But as Christians, we can express our informed sense that many Christians would find it problematic if "Jehovah" or "Allah" were substituted in place of the ubiquitous and purportedly inclusive "God" of JudeoChristianity. ${ }^{106}$ Whether one pledges allegiance to the United States, for example, as nation under "Jehovah," "Allah," or "God," is not a matter of indifference to American Christians, ${ }^{107}$ just as we expect that it is not a matter of indif-

because they orient themselves to a set of ideas that includes elements that comprise the essence of Judaism. Conversely, Jews do not orient themselves to a set of ideas that includes elements that comprise the essence of Christianity."); id.; accord Suzanna Sherry, Religion and the Public Square: Making Democracy Safe for Religious Minorities, 47 DEPAUL L. REV. 499, 504-06 (1998) (similarly observing that "the common appeal to a purportedly Judeo-Christian tradition" ignores "that Jews are not Christians"); Silk, supra note 47, at 78-79 (detailing numerous ways in which Christianity theologically contradicts Judaism); see also Martin E. Marty, A Judeo-Christian Looks at the Judeo-Christian Tradition, 103 THE CHRISTIAN CENTURY 858, 859 (1986) (arguing that literal and metaphorical violations of the Jews "have provided the main plot of JewishChristian interaction," and that a proper account of the "Judeo-Christian tradition" would have as its largest component stories "about imposed ghettos, pogroms, persecutions and killings").

106 Cf. Epstein, supra note 30, at 2084-86 (imagining a predominantly Muslim United States pervaded by official references and appeals to "Allah," in which most Christians and Jews would feel like outsiders); George Cardinal Pell, Islam and Us, FIRST THINGS (June/July 2006), at 34 ("It is true that Christianity, Judaism, and Islam claim Abraham as their father and the God of Abraham as their God. I accept, with reservations, the claim that Jews, Christians, and Muslims worship the same God, but this has been disputed, not only by Christians but by Muslims as well. It is difficult to recognize the God of the New Testament in the God of the Qur'an, and two very different concepts of the human person have emerged from the Christian and Muslim understandings of God. This has had significant consequences for the different cultures that Christianity and Islam have given rise to and for the scope of what is possible within them.").

107 A powerful example that Judeo-Christianity does not function as an inclusive monotheistic civil religion was provided by the widespread outrage expressed by many religious conservatives, including one member of Congress, at the prospect that Keith Ellison (D-Minn.), a Muslim newly elected to Congress, would take his oath of office on the Qur'an rather than the Bible. See Amy Argetsinger \& Roxanne Roberts, But It's Thomas Jefferson's Koran!, WASH. PosT, Jan. 3, 2007, at $\mathrm{C} 03$ (reporting that Rep. Virgil Goode (R-Va.) called Ellison's plan to take the oath on the Qur'an a threat to American values), available at http://www.washingtonpost.com/wpdyn/content/article/2007/01/03/AR2007010300075.html; Andrea Stone, Newly elected Muslim lawmaker under fire, USA TODAY.COM, Dec. 1, 2006, available at http://www.usatoday.com/news/washington/2006-12-01-muslim-lawmaker_x.htm (reporting view of conservative radio talkshow host Dennis Prager-who is, apparently and ironically, Jewish--that Ellison should not be permitted to take the oath on the Qur'an "because the act undermines American culture," and that a representative is who is unable to take the oath of office on a "Christian Bible" should not serve in Congress); see also KARST, supra note 54, at 158 (relating strong and widespread negative public reaction to invocation by Buddhist priest at state university graduation ceremony in the early 1990s). Goode's and Prager's views drew widespread support in the conservative blogosphere, but were condemned by at least one prominent religious conservative, Kevin Hasson, president of The Beckett Fund for Religious Liberty. See Stone, supra. 
ference to Jews, Muslims, or adherents to other theistic faiths. ${ }^{108}$ The "God" of Judeo-Christianity is not a nondenominational term, ${ }^{109}$ any more than the Ten Commandments constitute a nondenominational symbol whose meaning is shared by all or nearly all Americans. ${ }^{110}$ Insistence on the inclusive nature of either echoes the insistence of Nineteenth century Protestants that "nonsectarian" Christianity was not essentially Protestant, "11 and the parallel assumption of the 1950s that all Americans could fit under the religious umbrella held up by Protestants, Catholics, and Jews. ${ }^{112}$

\section{Sectarian Meaning}

Finally, the Commandments are not just religious or Christian, but also sectarian. Their symbolic meaning now excludes even many Christians, a purpose betrayed by the consistent choice of the version of the Commandments that appears in the Kings James Bible instead of the different versions found in the Catholic Douay and Hebrew Bibles. ${ }^{113}$ For example, the King James's prohibition on the worship of images excludes those who venerate icons, such as Roman Catholics and the Eastern Orthodox. ${ }^{114}$ The official government disap-

108 See, e.g., FELDMAN, supra note 11, at 230 (observing that Muslims consider the Bible "a preliminary, imperfect revelation, unlike God's definitive teaching, found only in the Qur'an"); Steven H. Shiffrin, The Pluralistic Foundations of the Religion Clauses, 90 CORNELL L. REV. 9, 70 (2004) (suggesting that Buddhists, along with atheists and agnostics, resent having to send their children to public schools that recite a pledge to a nation "under God"). But see Smith, supra note 14 , at 8, 21 (suggesting that the proper inquiry should not be whether the words "under God" are "religious," but whether they are "unnecessarily [and] gratuitously religious").

109 See, e.g., Douglas Laycock, Theology Scholarships, the Pledge of Allegiance, and Religious Liberty: Avoiding the Extremes, but Missing the Liberty, 118 HARV. L. REV. 155, 226 (2004) (arguing that the Pledge is a profession of faith that implies a set of particular religious beliefs, including that God exists, that there is only one God, and that this God exercises controlling authority over the United States); id. at 226-27 n.458 (noting others who believe that the Pledge implies that the United States is under God's judgment, that government is limited by God, and that God is transcendent).

110 See Paul Finkelman, The Ten Commandments on the Courthouse Lawn and Elsewhere, 73 FordHAM L. REV. 1477, 1498 (2005). ("For an increasing number of Americans, the Ten Commandments have no religious significance. [W] hile the Ten Commandments speak directly to Jews, and indirectly to Christians, they have no relevance to the religious life of people who are not of these faiths.").

111 See text accompanying notes 34-36 supra.

112 See text accompanying notes 43-46 supra.

113 Professor Finkelman has persuasively demonstrated that even the choice of a version of the Commandments is sectarian. See Finkelman, supra note 110, at 1480-98. See also Glassroth v. Moore, 335 F.3d 1282, 1299 n.3 (11th Cir.) (observing that the different versions of the Commandments reflect "deep theological disputes" (quoting Steven Lubit, The Ten Commandments in Alabama, 15 CONST. CoMmENT. 471, 474 (1998))), cert. denied, 540 U.S. 1000 (2003).

114 E.g., CATEChism of THE CATHOLiC CHURCH nos. 2129-2132 (John Paul, Bishop ed. 1993), available at http://www.va/archive/ccc/index.htm (explaining the Catholic Church's interpretation regarding "graven images"); see Bill Broadway, A New Judgment Day for Decalogue Displays, 
proval of blasphemy, coveting, Sabbath-breaking, and parental disrespect implied by a display of the Commandments is also offensive to many American Protestants whose faiths condemn such behaviors but also adhere to the reformist Anabaptist precept that government enforcement or encouragement of religious faith corrupts and cheapens it. ${ }^{115}$

But even more than particular theological precepts implicit in any of the Commandments or in the choice of any of their versions, government display of the Commandments now signifies a particular normative understanding of the relationship between church and state in America held by evangelical and other theologically conservative Protestants. This view holds that the United States is fundamentally a "Christian" nation (by which is meant an "evangelical" or "conservative Protestant" nation), ${ }^{116}$ and includes belief that the "Christian" nation of the United States has a destiny defined by "Christian" beliefs, that the "Christian" God watches over his "Christian" nation, and thus that recognition and even worship of this God is essential to preservation of American peace and prosperity. ${ }^{117}$ The evangelical God now defines the God of Judeo-Christianity,

WASH. Post, Oct. 23, 2004, at B09 (reporting view of some scholars that the Protestant version of the Commandments prohibiting worship of images had its origin in Reformation efforts to rid churches of statues of saints).

115 See William R. Estep, The ANabaptist Story 261 (3d ed. 1996) ("The separation of church and state was viewed as necessary because of the nature of the church. Only thus could the church be cleansed and freed to be the church under God. The disestablishment of the state churches was for the Anabaptists the minimum requirement in a guarantee of religious freedom.); HAMBURGER, supra note 20, at 26-27 (recounting the Schleitheim Confession's conclusion "that it is not appropriate for a Christian to serve as a magistrate").

116 E.g., David Barton, The Myth OF SEPARATion (1992) (arguing that the founders intended the United States to be a Christian republic); FrANKY SCHAEFFER, A TIME FOR ANGER: THE MYTH OF NEUTRALITY (1982) (arguing that the Constitution was constructed from "Christian principles" and was intended to be "interpreted in the light of the Judeo-Christian tradition"); SOUTHERN Baptist Convention, Resolution on Secularization of Our Culture (2004) (declaring that "America was founded upon principles derived from God's Word and expressed in JudeoChristian values"; concluding that "America's only hope is a spiritual awakening by the power of God through the Gospel of Jesus Christ," and calling for "Christians everywhere to aggressively advance the Kingdom of God"), available at http://www.sbc.net/resolutions/ amResolution.asp?ID=1135; see WALTER H. CAPPS, THE New Religious Right: PIETY, PATRIOTISM AND POLITICS 6 (1990) (describing fundamental tenets of the religious right movement as including the "understanding that the United States of America is a 'Christian nation' in some literal sense" and the need to "bring religious beliefs and political ideals into mutually sustaining alignment," so as to "stabilize the vitality of the nation's common life"); Jacob Heilbrunn, Neocon v. Theocon, NEw REPUBLIC, Dec. 30, 1996, at 20, 22 (characterizing the religious right as a "new Thomist movement" that "embrace[s] explicitly the notion of a Christian nation" and "accepts the idea of a transcendent divine law that carries universal obligations even for nonbelievers"); see also Heilbrunn, supra, at 24 (reporting Alan Keyes's statement that the founders understood the Declaration of Independence "to be a bridge between the Bible and the Constitution, between the basis of our moral faith and the basis of our political life").

117 These are the assumptions that underlaid Rev. Jerry Falwell's and Rev. Pat Robertson's belief that the 9/11 attacks were the fault of evil and sinful New Yorkers who had turned from God. See infra note 127 and accompanying text. See also Ledewitz, supra note 56, at 627 ("When America is viewed as in a special relationship with God, sin in America cannot simply be 
the personal savior of those who call upon him, the source of American greatness who must be thanked and acknowledged as the foundation of our government and our society. ${ }^{118}$

It is precisely the sectarian Christian meaning associated with "JudeoChristian" symbols and practices that triggers such strong conservative Christian reactions to their removal from public life. ${ }^{119}$ During recent decades, conservative Christians have successfully projected potent theological meaning onto these symbols and practices, meaning that has long since overflowed the bounds of the generically thin Judeo-Christian tradition. ${ }^{120}$ Judeo-Christianity has become, in a word, "sectarianized."

\section{C. "Sectarianization" and the Return of Classic Tolerance}

The sectarianization of Judeo-Christianity by conservative Christians makes it difficult even for some monotheistic believers to see their beliefs reflected in its symbols and practices. For example, many conservative Christian leaders have publicly savaged Islam since 9/11. ${ }^{121}$ Reverend Jerry Falwell has "stated that Muhammad, the founder of Islam, was a terrorist," Robertson has referred to Muhammad "as 'a robber and a brigand," 123 and Rev-

tolerated as something one would expect from pagan non-believers. If America is the Church, sin must be prohibited by government just as $\sin$ is prohibited within the community of faith-within the Church. For instance, gay marriage cannot just be something that gays do in America that has nothing really to do with the Church. In this way of thinking, there is no conceptual space for the sin of non-believers. It generally follows in this perspective that America has an obligation to the world, much as the Church has the obligation in the New Testament to convert the world and much as Israel was to be a blessing to the nations.").

118 Cf. Marty, supra note 105, at 858-59 (observing that "not a few Jews and other Americans think that 'Judeo-Christian' is often a code word for those promoting a Christian America").

119 See Erwin Chemerinsky, Why Justice Breyer Was Wrong in Van Orden v. Perry, 14 WM. \& MARY BILL OF RIGHTS J. 1, 7 (2005) (observing that "those who favor the Ten Commandments on government property ... do so precisely because of the religious content of the Ten Commandments and the importance of the Decalogue as a religious symbol"); Shiffrin, supra note 108, at 70 (observing that the "firestorm" of criticism following constitutional invalidation of "under God" in the Pledge "itself demonstrated the religious character of the message and the tenacity with which it is held"); Zick, supra note 96, at 2310, 2371-72 (arguing that it was the sacred character of Moore's decalogue monument in the eyes of some Christian believers that accounted for their reacting "as if their very faith was under attack" when its removal from the courthouse was threatened).

120 See Massey, supra note 34, at 37-38 (arguing that sectarianization of public religious symbols by conservative Christian majorities was a predictable outcome of the Court's deference to legislative deployment of such symbols).

121 See UTTER \& TRUE, supra note 60, at 29 (observing that since 9/11, "many Christian groups and publications continued to emphasize the differences between Islam and Christianity and to proclaim the superiority of the Christian faith" despite widespread media criticism that this approach was "indicative of a hate-filled campaign of intolerance").

$122 \quad l d$. at 29.

123 Id. 
erend Franklin Graham, son of well-known evangelist Reverend Billy Graham and successor to his ministry, has accused American Muslims of endorsing the 9/11 attacks and characterized Islam as an "evil and wicked religion." 124 More recently, Pope Benedict, in an otherwise sensitive call for rational dialogue on religiously motivated violence, implied that Islam is "evil and inhuman" because its Qur'anic command to spread Mohammed's teachings "by the sword" violated God's nature. ${ }^{125}$

Such attacks are not only aimed at Islam but also at other faiths. Reverend Falwell has announced that the "Anti-Christ" of the New Testament is Jewish, ${ }^{126}$ and comparably vicious attacks by conservative Christians on Catholics, Mormons, and theological liberals are well-known. ${ }^{127}$ Thus, while it is true that Catholics, Jews, Mormons, and Muslims are all monotheists who accept the divine origin of the Commandments, the close association of the Commandments with hostile sectarian condemnations of their faiths may make it difficult for the members of these faiths to see themselves and their beliefs reflected in the symbolic meaning of the decalogue monuments.

During the years he lived in a small city in the deep South, Professor Gedicks was present for many public prayers offered at community events by conservative Christian ministers and lay believers. The sentiments expressed in these prayers, offered up to "God" or "our Father" in the name of Jesus, were nearly always consistent with his personal religious beliefs. Yet it was also true that clergy of the conservative Christian churches in the community regularly warned their members against the dangerous "cult" of the Mormons, to which

124 Esther Kaplan, With God ON Their Side: GeORge W. Bush ANd The Christian Right 82 (2004); UTTER \& TRUE, supra note 60, at 29.

125 Pope Benedict XVI, "Lecture of the Holy Father," Aula Magna, University of Regensburg, Germany (Sept. 12, 2006) (quoting 13th century Byzantine emperor), available at http://www.cwnews.com/news/viewstory.cfm?recnum=46474; see also Ian Fisher, Benedict XVI and the Church That May Shrink. Or May Not., N.Y. TimEs, May 29, 2005, at WK3 (noting that Benedict, as Cardinal Ratzinger, oversaw the issuance of a Vatican document which characterized non-Christian faiths as "deficient").

Even if one considers Benedict's use of this quotation ill-advised, however, the violent Muslim over-reaction to it seems to have confirmed the quotation's assessment of Islam. This incident also illustrates the ironic position of Roman Catholics, who can find themselves on both sides of the sectarianization of Judeo-Christianity, as critics of non-Christian religions like Islam, and objects of criticism by Protestant conservatives.

126 UTTER \& TRUE, supra note 60 , at 68.

127 See, e.g., KAPLAN, supra note 124, at 74 (reporting conservative Christian characterizations of the Roman Catholic church as the "church of the Anti-Christ," and The Church of Jesus Christ of Latter-day Saints, or "Mormon" church, as a "cult") (quoting Rev. Bob Jones, Jr. \& the Southern Baptist Convention, respectively); UTTER \& TRUE, supra note 60, at 71 (reporting that Rev. Falwell and Rev. Robertson both laid the blame for the 9/11 attacks on the World Trade Center to abandonment of traditional moral values by feminists, gays and lesbians, and other cultural liberals who reside in New York City). Professor Gedicks has argued elsewhere that Latter-day Saints occupy an ironic position in the culture wars similar to that of Roman Catholics, see supra note 124, as holders of conservative Protestant values whom Protestant conservatives nevertheless attack as cultists. 
Professor Gedicks belongs. Shorn of its context, this prayer language appeared open, benign, and ecumenically inclusive. For a person outside the conservative Christian majority like Professor Gedicks, however, it was impossible to ignore that this language was usually intended by its speaker and understood by most of its audience to have a sectarian meaning that did not include him.

Perhaps the best example of how conservative Christians have sectarianized the purportedly nondenominational symbols and observances of JudeoChristianity is their reaction to former Chief Justice Moore's defiance of a federal court order to remove his ostentatious decalogue monument from the state courthouse. Broad and deep conservative Christian support for Moore's insistence on maintaining the display, even in the face of adverse federal and state judicial decisions, "clearly demonstrate[d] the belief of conservative Christian groups that the American legal system depends on God-given law and that the nation must publicly recognize that dependence." ${ }^{28}$ In the wake of the Moore controversy and the Decalogue Cases, political conservatives in Congress introduced a jurisdiction-stripping measure that would have prevented federal courts from reviewing state court decisions upholding governmental acknowledgments of God irrespective of whether these are tied to America's religious history or heritage. $^{129}$ In introducing this proposed act, one of its co-sponsors criticized the separation of church and state and declared that the moral condition of the contemporary United States required the "reintroduction of God" into government and public society. ${ }^{130}$

Many Americans whose religious beliefs would seem to fall comfortably within the boundaries of Judeo-Christian civil religion are alienated from it because of the increasingly close association of its symbols and practices with conservative Christianity. ${ }^{131}$ The conservative Christian understanding of the

128 UTTER \& TRUE, supra note 60, at 74-75; accord FELDMAN, supra note 11, at 232 ("[Some] values evangelicals will not be especially disturbed to discover that some Americans might disagree with the prayers they offer in the workplace or the inspirational message Christian messages that some teachers in the South hang in their classrooms . . . [;] they may even argue that they are going to promote their beliefs because those beliefs are God's truth, worth fighting for even if the Constitution limits their public promotion. This tone of civil disobedience was heard among the supporters of Alabama Chief Justice Roy Moore, who were prepared to be arrested rather than to allow removal of the two-and-a-half ton granite Ten Commandments monument he had erected in the state courthouse in Montgomery."); KAPLAN, supra note 124, at 247 (observing that members of Focus on the Family "ranked Moore's fight [to install the Ten Commandments in the Alabama State Courthouse] as second in importance only to the signing of the partial-birth abortion ban").

129 See Safeguarding our Religious Liberties Act, H.R. 4576, 109th Cong. (2005) (proposed Dec. 16, 2005); Religious Liberties Restoration Act, S. 1558, 108th Cong. (2003) (proposed Aug. 1, 2003).

130 UTTER \& TRUE, supra note 60 , at 76.

131 Cf. Robert J. Bein, Stained Flags: Public Symbols and Equal Protection, 28 SETON HaLL L. REV. 897, 921 (1998) (arguing that the Confederate battle flag cannot act as a unifying symbol of the South because it excludes southern blacks who have equal claim with whites to the heritage of the South); Sanford Levinson, They Whisper: Reflections on Flags, Monuments, and State Holidays, and the Construction of Meaning in a Multicultural Society, 70 CHI.-KENT L. REV. 1081, 
meaning symbolized by Moore's decalogue monument is based on a narrow theological understanding of the meaning projected by displays of the Commandments to which many Jews, Mormons, Muslims, and even mainline Christians cannot authentically subscribe. This, of course, is not even to mention nonbelievers and adherents to non-Western religions and postmodern spirituality.

Conservative Christians have appropriated the symbols and observances of Judeo-Christianity with sufficient success that they no longer communicate theological breadth and inclusiveness, if they ever did. To the contrary, as the result of this sectarianization, Judeo-Christianity now symbolizes the classic toleration of non-Christians, marginalized Christians, mainline Christians, and others outside the bounds of conservative Christianity; that is, nonbelievers, non-Christians, and heterodox Christians are protected from persecution but not understood to be true equals in the collective tasks of self-government and in other dimensions of American public life. ${ }^{132}$ Since Judeo-Christian symbols and observances now combine sectarian and patriotic meanings, government deployment of such symbols and observances unavoidably communicates that conservative Christianity is properly and exclusively in charge of culture and politics in those communities subject to the deploying government. ${ }^{133}$

Sectarianization of Judeo-Christianity has clear doctrinal import. Establishment Clause doctrine is now largely informed by principles of religious

1100-04 (1995) (arguing that the legitimate Southern honor and pride signified by the Confederate battle flag cannot be disentangled from the racism it also signifies as a symbol of Southern resistance to abolition, desegregation, and African American civil rights) (discussing James Forman, Jr., Driving Dixie Down: Removing the Confederate Flag from Southern State Capitols, 101 YALE L.J. 505 (1991)).

132 Douglas Laycock, Church and State in the United States: Competing Conceptions and Historic Changes, 13 IND. J. GLOB. LEG. STUDIES 503, 531 (2006) ("The dominant view among evangelical Christians is that minority religions and nonbelievers should be fully protected from penalties and civil disabilities, with full protection for the free exercise of minority religions. But evangelicals also think that religion should be included in all important government functions, that of course the religion included will be broadly consistent with the majority's religious beliefs, and that no one could reasonably expect otherwise. Religious dissenters do not have to attend formal worship services, but if they want to attend public meetings, or send their children to public schools, supporters of government prayer say that of course they should have to sit through brief observances of the majority religion. In that sense, the majority religion would be preferred and supported by government, and all other religions would be tolerated."); see also Michel Rosenfeld, Derrida's Ethical Turn and America: Looking Back from the Crossroads of Global Terrorism and the Enlightenment, 27 CARDOzo L. REV. 815, 828 (2005) (describing Derrida's view that tolerance is a "Catholic virtue," historically rooted in the medieval church's selfconfident forbearance towards those "living in error," and thus not "a relationship among equals, but rather a concession by the powerful to the powerless, and one that is subject to change or revocation at will").

133 See KARST, supra note 54, at 149. 
equality and government neutrality. ${ }^{134}$ These principles generally prevent federal and state governments in the United States from acting or speaking as if a particular religion, or even belief generally, were metaphysically true or morally correct. ${ }^{135}$ Government use of sectarianized symbols and observances of conservative Judeo-Christianity would undermine, and could eventually eliminate, these doctrinal ethics of equality and neutrality. In that event, government would be re-empowered to define religious truth in accordance with the sectarian preferences of the majority, and religious minorities would have to endure the social marginalization that accompanies adherence to a tradition of belief or unbelief that falls outside the boundaries of the majority's version of Christianity. $^{136}$

The threat of majoritarianism to religious equality and government neutrality is perfectly captured in Justice Scalia's bald declaration that the overwhelming preference of American believers for monotheism justifies both governmental endorsement of monotheism and its corresponding disapproval of polytheism and other nonmonotheistic belief systems. ${ }^{137}$ Even setting aside that Justice Scalia has ignored both nonbelievers and nonmonotheistic believers, ${ }^{138}$ his argument proves too much. If the fact that $97 \%$ of American believers are monotheists suffices to immunize government displays of the Commandments from Establishment Clause attack, then the fact that nearly as many American believers are Christians would similarly suffice to insulate government endorsements of Christianity itself, as in, say, government declarations that "Jesus

134 Dan Conkle, The Path of American Religious Liberty: From the Original Theology to Formal Neutrality and an Uncertain Future, 75 IND. L.J. 1 (2000); Noah Feldman, From Liberty to Equality: The Transformation of the Establishment Clause, 90 CAL. L. REV. 673 (2002).

135 See, e.g., Andrew Koppelman, Secular Purpose, 88 VA. L. REV. 87, 108-09 (2002).

136 See, e.g., FELDMAN, supra note 11, at 222 (" $[E] v e n$ in the face of diversity, allowing citizens to use the government to express or give effect to religious belief enables some to exclude or disadvantage those who believe differently . . . . If the state is functionally Christian, how can Jews or Muslims be equal to Christians as citizens?"); Hall, supra note 95, at 80-81 (arguing that civil or "civic" religion "may force religious minorities to sever civil communion to avoid spiritual pollution," may cause separationists to forego "participation in civic occasions such as school graduation ceremonies to avoid contamination with prayers that create in their minds an unholy communion," and "will coerce citizens to deny their citizenship rather than submit to an unholy spiritual fellowship"); Massey, supra note 34, at 49 (arguing that the Court's Religion Clause doctrine of legislative deference may encourage government coercion by majorities "who seek to push the judicial boundaries of establishment further to the margins, particularly when the issue involves the degree to which religious ceremony should play a part in public culture"); Shiffrin, supra note 108, at 39 ("If a state is permitted to endorse a particular religion, formally creating insiders and outsiders on the basis of religion, there is good reason to fear that this formal marginalization will carry over to the social and economic spheres. Discriminating on the basis of religion would be subtly encouraged.").

137 See supra notes 2-4 and accompanying text.

138 See supra notes 58-61 and accompanying text. 
Christ [is] our Lord and Savior."139 One hopes that not even Justice Scalia would go so far.

In sum, at the same time that religious demographics in the United States have placed large numbers of Americans outside the boundaries of JudeoChristian civil religion, the sectarianization of Judeo-Christianity has shrunk the theological landscape marked by these boundaries, making it doubly unlikely that Judeo-Christianity can function as the social and political unifier that civil religion is supposed to be.

\section{Conclusion: The Past That Is No Longer Present}

There is an unmistakable nostalgia attached to conservative Christian efforts to reclaim the symbols of Judeo-Christian civil religion. These symbols are being used to recall American society to the 1950s, when Judeo-Christianity formed the foundation for the "religious people" of the United States, ${ }^{140}$ if not to the 1890 s, when "nonsectarian" Christianity formed the foundation of a "Christian nation." "141 The sectarianization of Judeo-Christianity exhibits one of the signal attributes of religious fundamentalism: recourse to the past in reaction to uncertainties and upheavals triggered by contemporary life. ${ }^{142}$ Fundamentalism looks back to an idyllic time when traditional religious values are thought to have underwritten a social order and stability that economic, political, and cultural liberalization have undermined and surpassed. ${ }^{143}$

But this older order cannot be restored. Liberal democracy seeking to establish or maintain itself in a social condition of religious pluralism does not flourish when infused with thick religious values. ${ }^{144}$ In such conditions, liberal

139 See Jack Balkin, Justice Scalia Puts His Cards on the Table, Balkinization, June 27, 2005, available at http://balkin.blogspot.com/2005/06/justice-scalia-puts-his-cards-on-table.html ("[W]hy did Jews and Muslims get thrown in the mix of first class religious citizens? After all, if you exclude them you still have about $91 \%$ of the population. So why couldn't the government offer prayers to Jesus Christ, our Lord and Savior? Why couldn't we say that 'Invocation of [a Christian] God despite ... the beliefs [of non-Christians] is permitted not because [non-Christian] religions cease to be religions recognized by the religion clauses of the First Amendment, but because governmental invocation of [Christ] is not an establishment."') (quoting and interlineating McCreary County v. ACLU, 545 U.S. 844, 899-900 (2005) (Scalia, J., dissenting)).

140 Zorach v. Clauson, 343 U.S. 306, 313-14 (1952).

141 Holy Trinity Church v. United States, 143 U.S. 457, 471 (1892).

142 Gedicks, supra note 63, at 1222; see Martin E. Marty, The Widening Gyres of Religion and Law, 45 DePaUl L. REV. 651, 660 (1996) ("It is often presumed, at least by the more nostalgic souls, that at certain moments-e.g., for the West, in medieval Christendom or, for America, in certain colonial situations of religious establishment-there was coherence because the legal sphere was coextensive with the religious.").

143 See Richard D. Brown, Modernzation: THE Transformation of AMERICAN LifE 1600 1865 , at 59, 98 (1976).

144 This is, of course, the Rawlsian argument. See JOHN RAWLS, A THEORY OF JUSTICE 448 (1971) ("In a well-ordered society, then, the plans of life of individuals are different in the sense that these plans give prominence to different aims, and persons are left free to determine their 
democracy depends on the development of thin, procedural values, which permit individuals to pursue their own conceptions of the good so long as they do not interfere with that pursuit by others. ${ }^{145}$ No set of values is sufficiently broad, and no civil religion sufficiently inclusive, to shelter all or nearly all of the citizens of a religiously plural country. ${ }^{146}$ To the contrary, linking patriotism and citizenship to civil religion in circumstances of religious pluralism will inevitably result in alienation of those portions of the population who cannot see themselves in the model citizen presupposed by the civil religion. ${ }^{147}$

The linkage of Judeo-Christianity to American politics and government only makes sense in a world that has already passed away. Civil religion was supposed to provide a substitute for the established church, a means of morally instructing and spiritually unifying the people so as to bind them to republican government. The irony of civil religion is that its invocation triggers the very disunity it was supposed to remedy. At the very time that religious pluralism has strained the ability of Judeo-Christianity to function as a plausibly national civil religion, conservative Christians have sectarianized the public meaning of Judeo-Christianity, thereby shrinking its inclusive possibilities even further. Even in its most latitudinarian mode, Judeo-Christianity alienates from their country ever larger minorities of unbelief, non-Western religion, and postmodern spirituality. At the same time, the efforts of conservative Christians to recall the sectarian meaning of Judeo-Christianity ensure that it will become increasingly sectarian, not latitudinarian. This improbable means of pursuing patriotic loyalty and national unity in the United States ought to be abandoned.

good, the views of others being counted as merely advisory."); accord Walzer, supra note 6, at 622 ("[I]t is very important that people whose views have had a religious formation learn to politicize them. They don't need to leave them behind when they enter the political arena, but they do need to surrender their absolutism.").

145 See RAWLS, supra note 144, at 396 (arguing for the general priority of rights over the good in a well-ordered society, and for a "thin theory" of the good which assures each member of society "equal liberty to pursue whatever plan of life he pleases as long as it does not violate what justice demands"); see also Walzer, supra note 6, at 633 (arguing that liberal democratic societies can actively seek to realize "this or that idea of the good society. What follows is simply that, so long as there are different ideas, no realization can be definitive. On the religious or ideological side of the line, the good society can have an absolute form; on the political side, it is always provisional").

146 See JOHn Rawls, Political LiBERALISM 38 (1993) ("Since there is no reasonable religious, philosophical, or moral doctrine affirmed by all citizens, the conception of justice affirmed by all citizens in a well-ordered democratic society must be a conception limited to what I shall call 'the domain of the political' and its values. [C]itizens individually decide for themselves in what way the public political conception all affirm is related to their own more comprehensive views.").

147 Cf. Bein, supra note 131, at 913 (arguing that for public symbols to function as a means of uniting citizens with their country, they "must advance a message that speaks inclusively to the citizenry. If a symbol represents a message of exclusion, rather than inclusion, it will deny those excluded full participation in public life ... [leaving] them with a sense of physical vulnerability, alienation, and displacement."). 
